\title{
Corrigendum: Psychophysiological Patterns Related to Success in a Special Operation Selection Course
}

\author{
Alberto J. Hormeño-Holgado ${ }^{1,2}$, Pantelis T. Nikolaidis ${ }^{3}$ and \\ Vicente J. Clemente-Suárez ${ }^{1,2,4 *}$ \\ ${ }^{1}$ Faculty of Sports Sciences, Universidad Europea de Madrid, Villaviciosa de Odón, Spain, ${ }^{2}$ Studies Centre in Applied \\ Combat (CESCA), Toledo, Spain, ${ }^{3}$ Exercise Physiology Laboratory, Nikaia, Greece, ${ }^{4}$ Grupo de Investigación en Cultura, \\ Educación y Sociedad, Universidad de la Costa, Barranquilla, Colombia
}

Keywords: military, perceived stress scale, combat, anaerobic training, endurance training

\section{OPEN ACCESS}

Approved by:

Frontiers Editorial Office,

Frontiers Media SA, Switzerland

*Correspondence:

Vicente J. Clemente-Suárez

vctxente@yahoo.es orcid.org/0000-0002-2397-2801

Specialty section:

This article was submitted to

Exercise Physiology,

a section of the journal

Frontiers in Physiology

Received: 07 October 2020

Accepted: 09 October 2020

Published: 03 November 2020

Citation:

Hormeño-Holgado AJ, Nikolaidis PT and Clemente-Suárez VJ (2020)

Corrigendum: Psychophysiological

Patterns Related to Success in a Special Operation Selection Course.

Front. Physiol. 11:614969. doi: 10.3389/fphys.2020.614969

\section{A Corrigendum on}

Psychophysiological Patterns Related to Success in a Special Operation Selection Course by Hormeño-Holgado, A. J., Nikolaidis, P. T., and Clemente-Suárez, V. J. (2019). Front. Physiol. 10:867. doi: 10.3389/fphys.2019.00867

In the original article, the reference for "El-On et al., 2003" was incorrectly written as "El-On, J., Ben-Noun, L., Galitza, Z., and Ohana, N. (2003). Case report: clinical and serological evaluation of echinococcosis of the spine. Trans. R. Soc. Trop. Med. Hyg. 97, 567-569. doi: 10.1016/S0035-9203(03)80031-7." It should be "Kato, T. (2012). Development of the coping flexibility scale: evidence for the coping flexibility hypothesis. J. Couns. Psychol. 59, 262-273. doi: 10.1037/a0027770."

The authors apologize for this error and state that this does not change the scientific conclusions of the article in any way. The original article has been updated.

\section{REFERENCES}

Kato, T. (2012). Development of the coping flexibility scale: evidence for the coping flexibility hypothesis. J. Couns. Psychol. 59, 262-273. doi: $10.1037 / \mathrm{a} 0027770$

Copyright $\odot 2020$ Hormeño-Holgado, Nikolaidis and Clemente-Suárez. This is an open-access article distributed under the terms of the Creative Commons Attribution License (CC BY). The use, distribution or reproduction in other forums is permitted, provided the original author(s) and the copyright owner(s) are credited and that the original publication in this journal is cited, in accordance with accepted academic practice. No use, distribution or reproduction is permitted which does not comply with these terms. 